\title{
WHAT PROVISIONS OF THE DINGLEY TARIFF REQUIRE REVISION
}

\author{
By Albert Clarke,
}

Secretary of the Home Market Club and former Chairman of the United States Industrial Commission.

For three years there has been a growing demand for a revision of the tariff, and now that the occasion is riper than it was, revision has been agreed upon and the preliminary work begun. I have been trying all the while to have some immediate revisionist file a bill of particulars, but without success, except that a few have said the iron and steel duties are too high, wool and woolens require overhauling, the lumber, pulp and paper duties should be repealed or reduced, all important raw materials should be put in the free list and reciprocity should be promoted. Most of these suggestions have been made in general terms and by men not engaged in the industries proposed to be affected. The time is now at hand when suggestions must become definite to be of any value.

The Republicans having resolved to maintain the policy of protection, and the Senate being assuredly Republican for four years, it is easy to prognosticate that whatever the Democratic policy may be (this article is written prior to the Denver convention), the revision that will take place will seek to readjust duties and regulations, bringing them up to date, rather than to enter upon any change of policy. All the free traders and many protectionists, however, think there should be a general reduction and few or no increases. Investigation has convinced me that they will have to be disappointed if Congress carries out the Republican promise, and this because of facts which I will proceed to state.

The present tariff was enacted in 1897. Except in one or two cases of the accumulation of several years' supply of imported products under its predecessor, it was in normal operation by 1900 . The test of a tariff as to whether or not it is too high, or not sufficiently protective, is seen in the imports of a series of years. 
The following table of our principal competing imports in 1900, I904 and 1907, which have been coming in over the Dingley duties in increasing volume, is the briefest possible statement of the items that suggest the possible need of higher rather than lower duties:

\section{Competing Imports Which Have Increased}

\begin{tabular}{|c|c|c|c|}
\hline Automobiles and parts of $\ldots \ldots \ldots \ldots$ & 1900. & $\begin{array}{c}1904 . \\
\ldots \ldots\end{array}$ & $\begin{array}{c}1907 . \\
\$ 4,041,025\end{array}$ \\
\hline Bone and horn, manufactures of $\ldots$. & $\$ 271,893$ & $\$ 249,515$ & 292,073 \\
\hline Books, music, etc. .............. & $I, 551,966$ & $\mathrm{I}, 907,6 \mathrm{I7}$ & $3,072,127$ \\
\hline Jrass, manufactures of $\ldots \ldots \ldots \ldots$ & $24,8 \mathrm{I} 6$ & 56,796 & $\ldots \ldots$ \\
\hline Breadstuffs, total $\ldots \ldots \ldots \ldots \ldots \ldots$ & $1,803,729$ & $3,247,503$ & $5,892,968$ \\
\hline Brushes $\ldots \ldots \ldots \ldots \ldots \ldots \ldots \ldots$ & $977,5 \mathrm{I} 3$ & $\mathbf{I}, 372,227$ & $I, 586,556$ \\
\hline Buttons and forms $\ldots \ldots \ldots \ldots \ldots$ & 592,501 & $892,6 \mathrm{I} 2$ & 936,085 \\
\hline Coal tar colors and dyes $\ldots \ldots \ldots \ldots$ & $4,890,072$ & $4,918,503$ & $5,635,001$ \\
\hline Mineral waters $\ldots . \ldots \ldots$ & 662,022 & 860,678 & $1,053,976$ \\
\hline Potash, muriate $\ldots \ldots \ldots \ldots \ldots \ldots \ldots$ & I,804,254 & $2,407,957$ & $3,860,555$ \\
\hline$\ldots \ldots \ldots \ldots \ldots \ldots$ & 269,739 & 366 & 400,200 \\
\hline$\ldots \ldots \ldots \ldots \ldots \ldots$ & $3,437,160$ & $4,403,794$ & $6,289,342$ \\
\hline Soda, total ... & $5,908,6 \mathrm{II}$ & $9,821,666$ & I $4,48 \mathrm{r}, 740$ \\
\hline nicals, total & $53,705,152$ & $65,294,558$ & $82,997,914$ \\
\hline late, manufactured $\ldots \ldots \ldots \ldots$ & 240,141 & 426,486 & 830,6 I I \\
\hline dutiable $\ldots \ldots \ldots \ldots \ldots \ldots \ldots$ & 926, I I I & I,I9I,29I & $1,846,289$ \\
\hline and parts of $\ldots \ldots \ldots \ldots \ldots$ & 344,440 & 621 & 610,060 \\
\hline tes and parts of $\ldots \ldots \ldots \ldots \ldots$ & I,406, I I I & 2,369, & 2,983, I I 3 \\
\hline manufactured $\ldots \ldots \ldots \ldots \ldots$ & 313,561 & 300 & $37 \mathrm{I}, 8 \mathrm{I} 6$ \\
\hline ig, dutiable $\ldots \ldots \ldots \ldots \ldots \ldots \ldots$ & $3 \mathrm{I} 8,4 \mathrm{I} 7$ & 263 & $1,218,346$ \\
\hline jute $\ldots \ldots \ldots \ldots \ldots \ldots \ldots$ & $\mathrm{I}, 327,2 \mathrm{I} 5$ & $\mathrm{I}, 307,23 \mathrm{I}$ & $4,330,530$ \\
\hline age $\ldots \ldots \ldots \ldots \ldots \ldots \ldots \ldots$ & 68,920 & 384,96 I & 407,997 \\
\hline aps $\ldots \ldots \ldots \ldots \ldots \ldots \ldots \ldots \ldots \ldots \ldots \ldots$ & $10,606,185$ & $14,630,647$ & 29, I 13,847 \\
\hline anufactures of fibres. & $30,974,034$ & $39,221,694$ & $67,028,070$ \\
\hline al dutiable $\ldots \ldots \ldots \ldots \ldots \ldots$ & $6,426,817$ & $8,6 \mathrm{ro}, 653$ & $10,780,075$ \\
\hline tal dutiable $\ldots \ldots \ldots \ldots \ldots$ & $9,744,413$ & I0,806,572 & I3,944,094 \\
\hline tal dutiable $\ldots \ldots \ldots \ldots \ldots \ldots$ & $12,020,300$ & $14,720,100$ & $2 \mathrm{I}, 345,833$ \\
\hline d manufactures of............ & $5,4 \mathrm{I} 3,3 \mathrm{I} 7$ & & $8,972,600$ \\
\hline Glass and glassware $\ldots \ldots \ldots \ldots \ldots$ & $5,037,931$ & $6,583, \mathrm{I} 68$ & $7,596,63 \mathrm{I}$ \\
\hline Glue $\ldots \ldots \ldots \ldots \ldots \ldots \ldots \ldots \ldots \ldots$ & 537,492 & 598,546 & 596,667 \\
\hline ler and explosives $\ldots \ldots \ldots \ldots$ & 383,150 & $730,86 \mathrm{I}$ & $1,211,308$ \\
\hline manufactures of $\ldots$ & 248,226 & 87,476 & 565,603 \\
\hline of ctraw etc & 734,633 & $\mathrm{I}, 237, \mathrm{I} 55$ & 2,$832 ; 226$ \\
\hline of cattle $\ldots \ldots \ldots \ldots \ldots \ldots$ & $19,408,217$ & ro,989,035 & $20,649,258$ \\
\hline$\cdots \cdots \cdots \cdots$ & 713,701 & $\mathbf{1}, 374,327$ & $\mathbf{I}, 974,900$ \\
\hline Copper, manufactures of $\ldots \ldots \ldots \ldots$. & & 35,929 & 82,542 \\
\hline Cork, manufactures of..$\ldots \ldots \ldots \ldots$. & 464,658 & 810,733 & $1,707,930$ \\
\hline
\end{tabular}


I900.

Cotton, manufactures of :

cloths, bleached or dyed $\ldots \ldots \ldots \ldots 8,156,301$

clothing, except knit .......... I,231,23 I

knit goods .............. 4,715,762

laces, edgings, etc. .......... 19,208,165

thread, yarn, not spooled ....... 5,272,49I

total manufactures of cotton ..... 41,296,239

China, not decorated ............. $1,081,685$

decorated $\ldots \ldots \ldots \ldots \ldots \ldots \ldots \ldots \quad 7,176,659$

Eggs $\ldots \ldots \ldots \ldots \ldots \ldots \ldots \ldots \ldots$

Emery, ground $\ldots \ldots \ldots \ldots \ldots \ldots \ldots \ldots$

wheels, files, etc. .............

Feathers, not dressed $\ldots \ldots \ldots \ldots \ldots \ldots$

dressed $\ldots \ldots \ldots \ldots \ldots \ldots \ldots \ldots$

artificial, and fruits $\ldots \ldots \ldots \ldots \ldots$

Flax, dutiable $\ldots \ldots \ldots \ldots \ldots \ldots \ldots \ldots$

Hemp, dutiable ................

India rubber, manufactures of $\ldots \ldots \ldots$

Iron and steel:

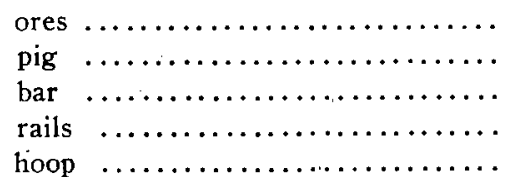

ingots, blooms, slabs ...........

wires and manufactures of ........

machinery $\ldots \ldots \ldots \ldots \ldots \ldots \ldots \ldots$

other manufactures of $\ldots \ldots \ldots \ldots$.

total iron and steel $\ldots \ldots \ldots \ldots \ldots$

Ivory, manufactures of $\ldots \ldots \ldots, \ldots$.

Lead, pig and other ...............

manufactures of $\ldots \ldots \ldots \ldots \ldots \ldots$

Leather $\ldots \ldots \ldots \ldots \ldots \ldots \ldots \ldots \ldots$

manufactures of $\ldots \ldots \ldots \ldots \ldots \ldots$

Marble and manufactures of $\ldots \ldots \ldots \ldots$.

Stone and manufactures of $\ldots \ldots \ldots \ldots$.

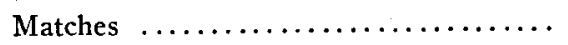

Matting of straw, etc ........... 2,674,9I I

Meat products ................. 471,315

Dairy products $\ldots \ldots \ldots \ldots \ldots \ldots \ldots \ldots$ 1,814,068

Metals and composition .......... 4,791,493

Musical instruments and parts ...... I,090,54I

Animal oils ................. 273,367

Mineral oils, free .............. 217,405

dutiable
I,497,022

2,109,50I

I,028,877

83,738

3I,749

$1,389,028$

386,316

$3,569,096$

$1,767,226$

49,418

142,469
13,781

I 32,674

$6,773,024$

812,606

215,944

I56,705

3,042
I904.

1907.

$\begin{array}{rr}8,144,383 & 12,727,769 \\ 2,505,035 & 3,771,189 \\ 6,044,691 & 8,671,848 \\ 24,848,764 & 39,756,502 \\ 5,060,533 & 6,940,261 \\ 49,524,246 & 73,704,635 \\ 1,337,381 & 1,257,051 \\ 10,193,072 & 11,885,680 \\ 61,458 & 26,276 \\ 90,932 & 216,061 \\ 12,547 & 17,749 \\ 2,742,018 & 4,401,1,31 \\ 171,339 & 1,772,380 \\ 2,432,496 & 3,332,001 \\ 2,541,874 & 2,254,112 \\ 869,260 & 1,534,371 \\ 1,157,042 & 2,519,661\end{array}$

I,593,277

4,047,167

I,366,097

I,190,536

70,281

$3,398,692$

722,580

$3,184,968$

$3,976,250$

$19,549,848$

74,497

3,838,734

2,788

772,610

6,190,984

1,408,433

263,941

230,867

$3,609,795$

844,960

$3,352,506$

$6,337,823$

I,366,285

638,591

247,906

32,840
$3,660,449$

$15,654,767$

1.669, 165

I33,936

129,100

$3,033,9: 8$

$1,33^{\circ}, \$_{52}$

$4,963,4<9$

3,057,44')

$33,633,075$

69,544

$4,364,890$

20,832

$\mathbf{5 9 7 , 4 4 9}$

$12,322,248$

I,569,476.

376,786

201,927

3,769,202

936,397

$\mathbf{5 , 8 3 2 , 0 3 5}$

$10,325,446$

I,498,724

344,358

I, I40,734

165,132 


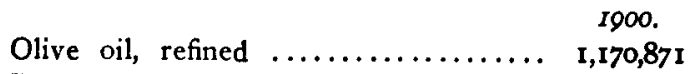

Paints and colors .............. I,535,46I

Paper, except lithograph and parchment $3,795,645$

Perfumeries

533,4 I I

Pipes and smokers' articles ......... 301,959

Rice, dutiable .............. I,875,609

Silk, manufactures of :

clothing $\ldots \ldots \ldots \ldots \ldots \ldots \ldots \ldots \quad$ I,657,641

laces and embroideries ........ 3,206,857

ribbons $\ldots \ldots \ldots \ldots \ldots \ldots \ldots \ldots \ldots, 1,811,644$

velvets, etc. $\ldots \ldots \ldots \ldots \ldots \ldots \ldots .2,316,115$

total manufactures of $\ldots \ldots \ldots \ldots .30,894,373$

Soap $\ldots \ldots \ldots \ldots \ldots \ldots \ldots \ldots \ldots \ldots \ldots \quad 623, \mathbf{1 4 4}$

Spirits, wines and malt liquors :

malt $\ldots \ldots \ldots \ldots \ldots \ldots \ldots \ldots \ldots \ldots \quad 1,727,256$

distilled $\ldots \ldots \ldots \ldots \ldots \ldots \ldots \ldots \ldots$ 3,609,83I

wines $\ldots \ldots \ldots \ldots \ldots \ldots \ldots \ldots \ldots$ 7,421,495

Straw and grass, manufactures of .... 336,287

Sugar, total ................ 100,250,974

Tobacco and manufactures of :

leaf $\ldots \ldots \ldots \ldots \ldots \ldots \ldots \ldots \ldots \ldots \ldots 13,297,223$

manufactures of $\ldots \ldots \ldots \ldots \ldots \ldots, 2,364,137$

Toys $\ldots \ldots \ldots \ldots \ldots \ldots \ldots \ldots \ldots \ldots \ldots .2,923,984$

Vegetables . ................. 2,935,077

Wood and manufactures of :

sawed lumber, dutiable ......... 7,495,509

pulp .................... $2,405,630$

total dutiable, manufactures of.... I4,635,340

Wool and manufactures of :

Class I-clothing, dutiable ....... 8,009,985

Class 2-combing, dutiable ....... 2,633,721

Class 3-carpet, dutiable ........ 9,617,230

total unmanufactured . . . . . . . 20,260,936

Manufactures of :

clothing, except knit .......... 992,619

cloths $\ldots \ldots \ldots \ldots \ldots \ldots \ldots \ldots \ldots \ldots$ 5,129,529

dress $\ldots \ldots \ldots \ldots \ldots \ldots \ldots \ldots \ldots \ldots . \quad \mathbf{5 , 8 7 2 , 0 8 5}$

knit $\ldots \ldots \ldots \ldots \ldots \ldots \ldots \ldots \ldots \ldots$ 495,961.

shoddy and noils ............ $\quad 86,887$

yarns $\ldots \ldots \ldots \ldots \ldots \ldots \ldots \ldots \ldots .129,688$

total manufactures of $\ldots \ldots \ldots \ldots, 16,164,446$

Total dutiable imports $\ldots \ldots \ldots \ldots \ldots \ldots \$ 182,704-318$

Per cent of free $\ldots \ldots \ldots \ldots \ldots \ldots \ldots \ldots=\sqrt[43.21]{ }$

$\begin{array}{rr}8,573,494 & 21,378,304 \\ 2,819,822 & 3,235,281 \\ 13,420,275 & 16,920,443 \\ 24,813,591 & 41,534,028\end{array}$

$2,313,325 \quad 3,408,763$

$4,957,507 \quad 6,886,691$

$9,391,870 \quad$ II $, 808,781$

$508,358 \quad 725,861$

$71,915,753 \quad 92,852,253$

I6,939,487 26,055,248

$3,133,859 \quad 4,137,127$

$4,977,389 \quad 6,993,561$

$\mathbf{7 , 0 0 8 , 6 0 2} \quad \mathbf{5 , 7 2 8 , 4 7 2}$

$8,878,474 \quad 16,255,350$

$3,602,668 \quad 6,348,857$

$\mathrm{I} 8,565, \mathrm{I} 80 \quad 31,576,546$

$\begin{array}{rr}8,573,494 & 21,378,304 \\ 2,819,822 & 3,235,281 \\ 13,420,275 & 16,920,443 \\ 24,813,591 & 4 I, 534,028\end{array}$

$1,309,995 \quad 1,674,915$

$4,158,597 \quad 5,732,200$

$8,205,835 \quad 9,240,245$

$515,747 \quad 210,856$

$52,697 \quad 271,116$

$112,925 \quad 154,668$

$17,733,788 \quad 22.321,460$

$\$ 5.36,957.131 \quad \$ 790391,664$

4582

44.90 
The table shows that before the panic of October, 1907, there was a steady and in many cases a large increase in imports. It covers more than three-quarters of the total dutiable imports. It proves conclusively that the duties are far from prohibitory, and that in some cases they are not adequately protective, if protection is to be the policy of the country. Some increase was natural, owing to gain in population and purchasing power, but domestic industry should be allowed to meet most of the increasing demand, hence Congress will naturally take each case of large increase and inquire whether or not the prosperity of the domestic production of the article has been affected.

Anticipating that inquiry, I have by circular asked one thousand manufacturers and merchants what tariff changes the experience of their own business suggests. In replying, a few have followed the vogue of the last three years and in general terms recommended reduction all along the line, giving no specific reasons for it, and not confining themselves to their own business. This, of course, is not helpful. Many, however, particularize and in most cases show that present duties should be increased, or the classification or basis of computation changed, or that customs regulations should be modified so as to effectuate and not defeat the law. This information, like the foregoing table, will doubtless be a great surprise to most of those who have called for reduction, and yet no honest protectionist can ignore or lightly consider it, because it is the result of experience. As briefly as possible I will specify some of the changes thus far suggested.

I. Lithographs (included in "books, music, etc," in the foregoing table). The importation has doubled in seven years, although our people are amply equipped to meet their own needs. There is an obvious incongruity in the duty of 20 cents a pound on paper not exceeding .008 of an inch in thickness, and only 8 cents on paper between .008 and .020, exceeding 35 square inches in size and less than 400 square inches; for show cards $16 \times 24$ of the first class, weighing Ioo pounds per 1,000 , bear a duty of $\$ 20$, while an equal number and size on a slightly heavier paper, say .009 of an inch thick, weighing II 2 pounds, bear a duty of only $\$ 8.96$. Then if the size is changed to $4 \mathrm{I} 6$ square inches, the duty is ad valorem. There are no technicalities in the business which sall for these distinctions. Congress can easily substitute a compound duty which will 
be simpler and more effective. The wage of a skilled lithographer in Germany is about 30 marks (\$7.14) a week. Similar work here commands $\$ 22.00$ to $\$ 50.00$.

2. Brushes. It will be seen by the table that the import has increased 60 per cent under present duties. A western manufacturer writes that his strongest competitors are now the Japanese. Their wages do not average more than 25 cents a day, while he pays an average of $\$ \mathrm{I} .55$. Clearly the duties need raising if labor is to be protected, and certainly $\$ 1.55$ a day is not too much, where skill is involved.

An eastern manufacturer writes that imports are one-fourth of the country's supply. He thinks that instead of being reduced the duty should be raised to 50 per cent for protection against Europe alone. It is now 40.

3. Brush Fibres. Tampico or istle is now in the free list and should remain there, because it is not produced in this country. It is dressed in this country by machinery made at Burlington, Vt., which does better than hand work and at one-half the expense. This industry is protected (partially) by a duty of 20 per cent. It has recently transpired, however, that in England the purchasers of this machinery cannot afford to operate it, although the wage paid is only one-half that paid here, because of the competition from Germany and Belgium where wages are so much lower. Do these facts suggest lower or higher duties in the United States?

4. Cotton Manufactures. With a larger and better equipment in this country than ever before, seventy-three million dollars' worth of cotton goods were imported last year. The table shows great increases of nearly all kinds. Thus far not one manufacturer or merchant has specified to me a duty that he thinks can be reduced with safety, but two have said that the coarse goods would suffer least from it. Laces, edgings, embroideries and fancy weaves are the newest domestic cotton manufactures, and they have to compete with almost the cheapest labor in Europe. This competition has practically doubled in the last seven or eight years. The same is true of cotton knit goods, especially under the new administrative arrangements with Germany and France. Yet prices have not increased correspondingly with the prices of raw cotton and other supplies and with wages.

Last year's import of cotton manufactures equaled the total (276) 
production of three of the largest cotton manufacturing cities in this country-Fall River, Lowell and New Bedford. It nearly equaled the product of Maine, New Hampshire and Rhode Island combined. It surpassed the product of all the Southern states except the two Carolinas, and of all the Middle and Western states combined. It is a tremendous fact to be reckoned with, and as cotton machinery has been very largely increased during the last five years in England, Germany, Italy, and Japan, and the cost of ocean transportation is so small as to afford little or no protection, what changes in our duties do these facts suggest?

5. Clocks and Watches. The introduction of American machinery in Europe has naturally resulted in an increased import of watches. Sales of certain American watch movements abroad at lower than home prices and their reimportation for advertising purposes (as is claimed by domestic manufacturers), have created some public demand for lower duties. The great Waltham works are now closed for want of orders. Domestic manufacturers have not yet indicated what, if any, changes in duties are needed. Prices are so low that every citizen can own a good watch if he is in the least thrifty.

6. Corundum. Nearly all the pure corundum that is used in this country comes from Canada and pays a duty of $\$ 20$ a ton, which is considered to be for the protection of a patented artificial product which is said to be marketed under restrictions that amount to favoritism. A manufacturer of grinding wheels thinks the present duty a misapplication of protection.

7. Fibers and Manufactures of. The large increase in the import of jute bagging, bags and burlaps does not seem to cause domestic manufacturers to ask for a change of duties, but probably the anomaly of the situation will of itself call for investigation by Congress.

8. Hides of Cattle. The agitation of this subject two or three years ago quieted down after the Democratic leaders in Congress gave notice to the shoe manufacturers that they would not consent to a repeal of the $\mathrm{I} 5$ per cent duty without a guaranty of reduction in the prices of shoes. As the shoe and harness industries have greatly prospered, the duty is not considered a serious burden, and the agitation for its repeal was largely political. One of the 
worst effects of the duty grows out of the drawback on exported leather. The foreign buyer demands and usually gets a concession of the whole or a part of this drawback and thus has an advantage over the domestic buyer. A large manufacturer of shoes suggests that if the duty cannot be repealed the drawback had better be.

9. Iron and Steel. The greatest demand for revision has been directed against the iron and steel schedule. It is the cause of the agitation carried on by the National Association of Manufacturers, which is dominated by the vehicle and implement and agricultural machinery manufacturers and some other large consumers of iron and steel. They claim that by reason of the duty, or of combination, or both, the iron and steel producers have been making excessive profits, although their calculations do not allow for the cost of developing mines and transportation facilities and the substitution of new for old processes. Neither have they given the producers credit for maintaining steady prices during a period of great and increasing demand, when higher prices could have been exacted.

It remains to be seen what effect the reduction in prices on sheet and tin plates, which was made early in the year, and on iron ore, billets, sheet bars, plates, structural iron, merchant pipe and wire nails, which was made on the 9th of June, will have on the demand for a reduction of duties. The above table, however, shows considerable gains in imports of nearly all iron and steel shapes, and as there are European syndicates formed for the purpose of aggressive exploitation of foreign markets, changes should come only after exhaustive inquiry, if at all.

Although the largest corporation in the world has been formed in this industry, domestic competition and foreign competition have both increased under present duties, and if the duties are reduced the domestic competitors of the so-called trust will be likely to suffer more than the trust itself. This was the testimony of many independent manufacturers before the industrial commission. The force of this domestic competition, which is claimed as one of the triumphs of the protective policy, is seen in the recent reduction in prices. There are people who think that American industries, whether combined or not, which cause an economic price by large development and by concessions to normal market conditions, are of more importance to the country than any possible benefits derivable from abroad. 
Io. Oil, Mineral. It has been suggested, not from the industries, but by tariff reformers, that a fraud was perpetrated upon the country by adding an exception to the mineral oil clause in the free list, making the import dutiable when it comes from a country which puts a duty on our oil. There does not seem to be proof of any fraudulent intent, and the reasonableness of the exception is evident. The import of dutiable oil, though small, has largely increased and there is a much larger import of free oil, which shows that the claim that only one country could send it to us is not true. It should be borne in mind that the Standard Oil Company is not the only domestic producer and that if it were it is entitled to justice. The relative smallness of the import to the domestic product, however, makes the duty too small to talk about.

II. Paper and Pulp. The unfinished hearing by the Mann committee went far enough to convince the majority that the duty is not responsible for the advance in price and that if it were repealed or reduced, foreign exporters and not domestic consumers would get the benefit. The demand for repeal was made by well-known advocates of free trade, who had become officers of the American Newspaper Publishers' Association, and although the association gave them authority to attack the duty, the facts had not then been developed, and many of the members now sustain the committee's finding. In the general revision there may be some change in the duties, but no change is probable which will aim a blow at the pulp and paper industries.

12. Silk. Not one recommendation has been received for modifying the silk duties. Although the import is still large, the domestic product has steadily increased and become so variegated that only special patterns now need to be brought from abroad. It is a testimony at once to the wise adjustment of the duties and to the enterprise and skill of American manufacturers that this important industry is so well established and so prosperous and that its products are so reasonable in price that no demand seems to have arisen for any important changes of duty. The industry has fully justified its protection. The value of the domestic product has increased from $\$ 87,298,454$ in 1890 to $\$ 133,288,072$ in 1905 .

I3. Starch. The duty, $\mathrm{I} / 2$ cents a pound, applicable also to all preparations used as starch, was collected for a year or two and then by some strange ruling it was no longer applied to tapioca 
and sago flours, which are largely used as substitutes for potato and corn starch. The import of these flours last year was 58,391,075 pounds. The government lost its revenue and the starchmakers lost their protection. Starch making is threatened with ruin unless this mistake in administration is corrected.

14. Sugar. Strictly this article does not belong in the foregoing table of imports which have increased, because sugar imports have declined, but $I$ wish to call attention to the fact that they are still large. Our sugar beet production has increased so rapidly as to indicate a continuance of present duties. In 1905 there were fifty-one establishments, with a daily capacity of 35,900 tons of beets. They were located in fourteen states and territories. In five years there was an increase of 70 per cent in the number of establishments, I77 per cent in the capital, Ior per cent in the number of wage earners, 127 per cent in wages paid, and 233 per cent in the value of the product-all this in spite of freer importation of cane sugar from our insular possessions and from Cuba. The only demands for reducing the duties are from consumers or competitors, and they are much less insistent than they were a few years ago, because the increasing supply tends to reduce the price.

15. Wood and Manufactures of Wood. There has been a great demand for reduction or repeal of the duties on lumber, on account of the large advance in price and a fear that we are too rapidly using up our supply. It is now admitted, however, that the price is not chargeable to the duty, for it remained the same for some time after the duty was enacted, and that if the duty were to be taken off the price would remain the same while the demand is great. The only effect of repeal, therefore, would be that our treasury would lose the duties and foreign exporters would save them. It should be added that this would slightly conserve our forests, but only at the expense of employment. Logs for boards and pulp are already admitted duty free.

Where scientific forestry is practiced there can be a large annual cut without exceeding the growth, and it would seem that this is the direction which the legislation should take rather than repealing the duties and turning one of our largest industries over to Canada. In I905 there were in all parts of the country 19,127 saw and finishing mills, with a capital of $\$ 517,224,128$, employing 404,626 wage earners, and turning out a product valued at $\$ 580$,- 
022,690. This does not include the great industry of logging, in which there were I2,494 establishments, with a capital of $\$ 90,454$,494 , and employing 146,596 wage earners, to whom $\$ 66,989,795$ were paid.

In view of the magnitude of the industry, its existence in every state and territory, the means which are coming into use for preventing waste and the planting that is taking place, besides the certainty that a repeal of duties will not reduce the price, the only recent suggestions of change in the tariff are to offset any export duty which the Canadians may place on logs. It cannot be known in advance precisely what form this should take.

16. Wool and Woolens. This is the most difficult schedule in the entire tariff, because wool growing must be protected and manufacturers must be allowed an extra duty to compensate for it. The present schedule is the result of years of conferences (battles some have called them) between the growers and the manufacturers and of long study by experts and by committees of Congress. While some of the manufacturers would like lower duties, particularly on carpet wool, and while dealers as well as manufacturers would like to substitute an ad valorem duty for a specific duty on heavy shrinkage wools, so that they would not have to pay for grease and dirt, yet the difficulties of agreeing are so great that most of them say they prefer a continuance of existing arrangements to the evils that they know not of. In products which have to compete with cotton goods, like hosiery, the wool duty is said to force a large use of poor shoddy, but just how to remedy it and still protect wool is an unsolved problem.

Notwithstanding other branches of agriculture have been increasingly profitable and tempting, sheep husbandry has held its own and gained moderately as a result of protection. The gain would have been much larger, especially in New England, New York and Ohio, but for the dog nuisance. An increase of sheep for both wool and mutton is most desirable, hence, in the interest of consumers, tariff changes of a discouraging character should not be made.

The woolen and worsted manufacture has made gratifying progress. In I 905 the capital employed in it was $\$ 370,86 \mathrm{r}, 69 \mathrm{I}$, the wages paid $\$ 70,797,524$, and the value of the product $\$ 380,934$,003 , the last item showing a gain of 28.3 per cent in five years. 
Improvement in the quality of the product was equally marked, some of the mills now turning out cloths that compare favorably with the best made abroad and at lower prices.

It remains true, as demonstrated by Senator Aldrich in 1894, that if the whole duty on wool were added to the cost of a five pounds suit that ordinarily retails for $\$ 20$, it would increase the cost only about sixty-five cents, and most of it would be shared by the manufacturer and dealer.

17. Works of Art. There seems to be a more general demand than ever before for a repeal of the duty on works of art. It was not designed and has not been maintained for protection, but for revenue only, although this has not been generally understood. Such works usually become a valuable possession of the public after a period of private ownership and are generally enjoyed by the public from the first. There will certainly be no opposition to the repeal on the part of protectionists.

Whether the duty is removed or not, the law should be amended so as not to exempt articles involving a great deal of labor, like large, polished and elaborately carved marble altars (not antiques), which are now made in this country at more than twice the foreign labor cost, and which are manufactures rather than products of individual genius.

18. Scientific Instruments. The exemption from duty of scientific instruments for educational institutions greatly discourages their production in this country, although the manufacture here is able to meet nearly every need. There is complaint of the injustice of requiring an industry that has to be conducted under the conditions of protection to sell under the conditions of free trade.

19. Better Administrative Features. The modifications of the treasury regulations embraced in the compact with Germany and since extended to other nations have developed strong opposition, and without doubt several changes in the law will be proposed to secure an execution according to its purpose. This subject is highly controversial and suggestions will necessarily await the testimony of experts.

20. A Customs Court. A leading New York business journal has recently proposed that a customs court be established, so as to relieve the over-worked district and circuit courts and secure a more prompt and expert decision of cases that are appealed from 
collectors and the board of general appraisers. This has for some time been a growing need and Congress will be likely to give it careful consideration.

The foregoing suggestions are presented as indicative rather than comprehensive. Once revision is entered upon there will be recommendations of many small changes, some of which will undoubtedly be found meritorious.

Rates and regulations which take into account only the difference between foreign and domestic labor cost are not up to date. When a foreign state-owned railroad carries goods for export at only one-half its domestic rates, it practically pays a bounty to its producers for exploiting foreign markets. Why should not that indirect bounty be offset by an extra duty, the same as a direct bounty is now? It is a practice for railroads and steamships to make joint rates on through bills of lading, and this has caused millions of dollars' worth of foreign goods to be delivered throughout the trunk and gulf line territory of the great Central West at a lower cost for freight than domestic industries can secure for a much shorter haul. Thus European crockery is delivered at St. Louis, Chicago and St. Paul for a smaller freight charge than is made to those points from Trenton, New Jersey. This practice must be broken up or protection will be largely nullified.

It seems appropriate to say in conclusion that if the protective party is again intrusted with power its revision should be based upon facts, and not upon clamor raised by the other party. If the facts do not justify reduction but call for increase, the party must have "the courage of its convictions." It has been common to say that only principles and not schedules are sacred. Schedules, however, become the expression of principles and are just as sacred as any other law while they last. Rates must be sufficient or protection fails. 